\title{
Pum Pum Rule Jamaican Dance: An Analytic Response to the Inability to Recognize Female Sovereignty in Dancehall
}

Leslie-Ann Fullerton

"All I want to be is a Jamaican Dancehall Queen. If this is not possible, I will be satisfied writing about women in Jamaican dancehall." - Leslie-Ann Fullerton.

Leslie-Ann Fullerton was born and raised in a Christian home in Jamaica. She later became a dedicated lover and participant of Jamaican dancehall as a dancehall "mogela" [model], which played an instrumental role in informing this essay. Leslie-Ann is currently a $4^{\text {th }}$ year student at the University of Toronto pursuing a double major in Caribbean Studies and Political Science. She was the 2012-2013 president and is currently the 2013-2014 Co-President of CARSSU. In reading this essay, Leslie-Ann hopes that the reader takes the advice of Chimamanda Adichie and beware of "The Dangers of Telling a Single Story" about a people and its culture. She implores the reader to look at women in Jamaican dancehall from a positive perspective.

Jamaican music has had a close relationship with expressing the island's various socio-economic and political stages. In ChudeSokeis's work, POST-NATIONALIS GEORGRAPHIES: Rasta, Reggae, and Reinventing Africa, ${ }^{1}$ the author traces Jamaica's societal changes through music. This includes analyzing the relationship between post-nationalism, Rastafarianism, Dancehall, and women response to these phenomenon. Particularly, the emergence of dancehall introduced a rise African women participating in overt sexual expressions that was considered indecent. In this light, dancehall was rejected by the "ideological underpinnings of the elite culture" ${ }^{2}$ and their desires to mold nationalism in Jamaica into a replica of European model. As a result, dancehall songs are considered slack if it addresses sexuality in an "indecent or crude manner," 3 and because it "openly defied

1 Chude-Sokie, Louis, 1994. "Post-Nationalist Geographies: Rasta, Ragga, and Reinventing Africa." The African Arts, (UCLA: James S. Coleman Published) Vol. 27, No. 4, pp. $80-84+96$

2 Stolzoff, Norman C. 2000 "Wake the Town and Tell the People: Dancehall Culture in Jamaica." (North Caolina: Duke University Press) p.68

3 Stolzoff, Norma. C. 2000 "Wake the town and Tell the People: Dancehall Culture in Jamaica." (North Carolina: Duke University press, 2000) p.104 
protestant" 4 moral values and code. Consequently, those who participated in dancehall, particularly female patrons, were perceived as "loose-or "slack" [as is described] in the Jamaican vernacular." 5 This resulted in women in dancehall to be labeled subjected to sexual objectification by male dancehall artist. This can be attributed to a class dichotomy where working class dancehall participants reject "Judea-Christian ideals"6 by embracing dancehall while the upper echelons subscribed to it. Another way to view this phenomenon is appreciating the fact that through dancehall, women transformed themselves from occupying peripheral positions to creating spaces of "affirmation and power" 7 in dancehall through sexual expressions. This dichotomy also renders observers unable to appreciate working class women actively creating a space where they are seen and heard in Jamaica's post-independent atmosphere. Foundation female dancehall artist Lady G, Lady Saw and Tanya Stevens will be juxtaposed against their male counterparts to highlight their response to chauvinism in dancehall, and how women created a liberating space for themselves in dancehall where they could be been and heard on their terms. This paper does not aim to romanticize dancehall by playing ignorant to misogynistic elements nor to its sexual objectification of women. Despites the persistence of these negative aspects, the focus of this paper is to analytically respond to the inability of observers to recognize female presence in Jamaican Dancehall as one of empowerment, liberation, and sovereignty.

\section{The Evolution of Dancehall}

Jamaica's polarized vision for nationalism placed women in pre-constructed spaces, while dancehall afforded women the freedom to their own space through sexual expression. After decolonization, Jamaica's elite and middle class initial idea for nationalism was heavily invested in "Judeo-Christian values," 8 which

\footnotetext{
4 Stolzoff, Norma. C Wake the Town and Tel the People. 105

5 Cooper, Carolyn. 2004 "Lady Saw Cuts Loose: female fertility Rituals in Dancehall" in Sound Clash: Jamaican Dancehall Culture at Large." (New York: Palgrave Publishers) p. 355

6 idib

7 Chude-Sokie, Louis, 1994. "Post-Nationalist Geographies: Rasta, Ragga, and Reinventing Africa." The African Arts, (UCLA: James S. Coleman Published pp. 82

8 Cooper, Carolyne. "Lady Saw Cuts Loose" Female Fertility Rituals in Dancehall" in Sound Clash: Jamaica Dancehall Clture at large" 2004
} 
dictated the proper conduct for Jamaicans. In addition, the elites and middle class Jamaicans wanted European "high arts of literature, sculpture, and classical music" to be entrenched in Jamaica's nationalism. ${ }^{9}$ Essentially, Jamaica's racially stratified elites and middle class wanted to perpetuate the "European culture"10 that persisted after decolonization in 1962.

On the other hand, Rastafarianism wanted Jamaica's nationalism project to be reflective of black consciousness. According to Chevannese, not only were Rastafarians actively resistant to "dominant oppressive" structures, but they were also advocates of Pan-Africans ${ }^{11}$ consciousness in Jamaica. The popularity of reggae music provided a space for Rastafarians to express their socio-economical and political frustrations both locally and internationally. The most notorious example of this phenomenon is Bob Marley the Wailers who critiqued Jamaica's oppressive structure and expressed Pan-African sentiments in songs like "Back to Africa," and "Rasta Waan Go Home"12 as a means to escape inequality. Unfortunately, Jamaicans grew increasingly frustrated with the country's socio-economic and political inequality, and began to reject Rastafarian music and it aim to repatriate to a "paradise in Africa."13 Particularly, the African Jamaican working class community became more invested in "having the best time possible here and now with their chosen space being in the dancehall,"14 The watershed of Rastafarian of consciousness and the prominence of reggae music was marked by the death of bob Marley and the "stoning of Bunny Wailers, ${ }^{15}$ who was the last living member of the Wailers in the late 1980s. This created a space where dancehall could take form and mature. As Dancehall became prominent, graphic sexual expressions by males became one of its characteristics. What came as a surprise and discontent for some was that the rise of dancehall music also came with the females taking part in the live theatre of dancehall.

\footnotetext{
9 Stolzoff, Norma.C "Wake the Town and Tell the People". P. 68

${ }^{10}$ Stolzoff, Norma.C "Wake the Town and Tell the People". P. 65

11 Chevannes, Barry. Rastafari (New York: Syracuse University Press.1994) p, 17.

12 Chude-Sokei, Louis. 1994 POST-NATIONALIST GEOGRAPHIES Rasta, Ragga, and Reinventing Africa. p80.

13 Stolzoff, Norman. C. wake the town and tell the people 99.

14 Idib

15 Chude-Sokie Po idib
} 
While the elite's vision of nationalism excluded Jamaica's working-class women, black nationalisms and Rastafarianism tended to limit women's voices and bodies to "some kind of revolutionary propriety. ${ }^{16}$ This can be seen in the supportive but limited role played by the I-Trees in Bob Marley and the Wailers. ${ }^{17}$ Both elitism and Pan Africanism had pre-constructed ideas of nationalism; ideas that the working class women did not create for themselves. In the end, the emergence of dancehall unintentionally achieved a sexual awakening of the black working-class women in an attempt to escape the limits of superimposed ideologies. It is in this context that the working class women became active in creating their own space through sexual expressions in dancehall with a "power that feared both" Jamaica's elite, middleclass, and Pan Africanist.

\section{Early Stage of Dancehall}

Despite the growing prominence of lyrics oriented toward women's sexuality and economic power in the 1980 s and early $1990 \mathrm{~S}$, they were still subjected to traditional gender ideologies. ${ }^{18}$

What appears to be frequently missing from discourse similar to that of the above are women's resistance to the constraints of gendered roles and how to it transformed dancehall. The 1987 song, "Round Table Talk," 19 is one of the first songs that challenged gender roles in dancehall. Papa San and Lady G's collaboration in the song juxtaposed traditional and modern understandings of gendered roles. In the below excerpt, Lady G's defiantly challenged this static and dated gendered mold as she transfers the gender roles duties to spouse becomes independent. This creates a conflict in the relationship. The lyrics are as follows:

\footnotetext{
16 Chude-Sokei, Post-National Geographies. Rasta, reggae, and Reinventing Africa P.82.

17 Idib

18 Stolzoff, Norman, C. Wake The Town and Tell the People" p. 106.

19 Papa San,ft Lady G. "Round Table Talk"

1987.http://www.youtube.com/watch?v=8UrnGOJhz_I
} 


\begin{tabular}{|l|l|}
\hline \multicolumn{1}{|c|}{ Lady G } & \multicolumn{1}{|c|}{ Papa San's Response } \\
One time gone you use to tell mi weh & Lady G a dis you wah dis? \\
fi do & Mi is a Mr.! \\
Chu mi neva did a work and want fi & Mi look like a mistress? \\
please yuh, & You ever si mi inna frock? \\
But now mi a work and you naaw do & You ever si mi ina slip? \\
nutt'n & Mi nuh wear make up nor put on \\
Just tan inna di yaawd and help do & lipstick \\
supp'n & \\
I gwine give you a list from start to \\
finish \\
$\begin{array}{l}\text { Stop bite yuh finga nail and start to } \\
\text { practice }\end{array}$ \\
\hline
\end{tabular}

As Lady G proceeds to give Papa San the list of house chores she expect him to complete-since she is now working and he "naaw do nutt'n," which implies Papa San is unemployed-she openly challenged the status quo of gendered roles in Jamaican dancehall. Feeling "disrespected" Papa San initiates an argument in protest, during which both reveals their infidelities and ends the relationship. This song was groundbreaking. Not only did it show women rejecting the constraints of gendered roles it also showed women being sexually autonomy in their refusing and choosing partners.

\section{The Rise of Female Power in Dancehall.}

It is important to admit that dancehall is extremely sexual. This is the core reason it appeals to its audience. One of the earliest and most persistent arguments against dancehall was based on its slack and indecent content. According to Stolzoff, the growing discontent with dancehall was seen in the elite's rejection "African working class social practices and the articulations in dance halls. ${ }^{20}$ These "social practices and "articulations" in dancehall referred to dancehall's highly sexually suggestive dances compounded by the fact that the messages expressed in dancehall were done in 'Patois' or 'Patwa'21 (Jamaican dialect) which was a characteristics of lower class Jamaicans.

20 Stolzoff, Norman.C. Wake the town and Tell the People,p. 68-77.

21 Stolzoff, Norman.C . Wake the town and Tell the People,p. 65 
Once female presence in dancehall became more prominent, they began to liberate themselves from the images of sexually accommodative and docility that was constructed by male artist. Take for instance this excerpt from Lady Saw's, controversial but nevertheless, legendary song "The Sycamore Tree" ${ }^{22}$ which is as follows:

Cho:
it was under the sycamore
tree
A bwoy waan mi bow
An mi tell him fi flee...
the sun stop shinin for
me...

\section{Cho:}

Verse 1:
Yuh used to drop yuh hint an
mi think yuh did a gyow
But mi a goody goody an mi
never know how
Furthermore mi never
deserve fi bow...
So mi naw mek nuh bwoy ...

Verse 3:
Mi love yuh but mi still
have mi pride
Mi a gal wi gi yuh all di
wickedest ride...
But a one mic mi chat pon
Ah mi studio mic...

In this song, Lady Saw debunks the sexually accommodative image of women in dancehall music. By refusing to "bow"23(Jamaican vernacular for oral sex), Lady Saw asserts her authority in determining what she is and is not willing to do sexually. This is a far cry from the earlier portrayal of women by male artists as, 'sexual objects'24 that fulfilled their sexual desires without reservations. She does, however, reassures her partner that even though she "nah go bow," her capabilities to give him "di wickest ride" 25 remains unfettered. As far as the above excerpt illustrates, "dismissing" Lady Saw as a "mere victim of patriarchy ...[who is]...robbed of all agency" 26 seems to be an incomplete and lethargic analysis of the artist and her contribution to the dancehall industry. Moreover, in her collaboration with Spragga Benz in the making of the song "Back Shot Mi Love," 27 while Spragga Benz clearly prefers to be "pan top" in the missionary style, Lady Saw clearly exhibits all her

\footnotetext{
22 Lady Saw, 2001 My Way

Lyrics"http://www.youtube.com/watch?v=8UrnGOJhz_I

23 Jamaican vernacular for giving oral sex.

${ }^{24}$ Chude-Sokei, 1994 Post-National Geographies. Rasta, reggae, and

Reinventing Africa. 83

25 Jamaican vernacular for satisfactory sex.

26 Cooper, Carolyne. Lady Caw Cuts Loos. 355

${ }^{27}$ Spagga Benz, Lady Saw“Back Shot Mi love” 2001. Way

Lyrics"http://www.youtube.com/watch?v=8UrnGOJhz_
} 
agencies by being vocal about which position will provide her with the maximum sexual satisfaction.

Tanya Stephens is also another female artist who has challenged misogyny in dancehall and has defined women's space in dancehall. In Tanya Stephens 1996 "You Nuh Ready Fi Dis Yet,"28 she calls into question the tendency for Jamaican males to associate over-exaggerated genital size and overexertion of sexual capability to being good lovers. This is highlighted when Tanya Stephens' song is place in the same space with that of male artist Little Lenny's 1992 "Bum Flick Pan Mi dick." 29 In this light, it is not difficult to imply her song tends to counteract Little Lenny's idea of good love making, even though they were released four years apart. Below is a juxtaposition of Little Lenny and Tanya Stephens' songs:

\begin{tabular}{|l|l|}
\hline Little Lenny: Bum Flick Pan mi Dick! & Tanya Stephens: Yuh Nuh Ready Fi \\
1992 & Dis Yet! 1996 \\
Intro: Calling Callin all stamina worker & Intro: Oi Mr Mention \\
Female custom brokers & Ask Yuhself this question \\
Heart Taker, Buddy breakers, & Unno say unno a don man \\
Tantalizing whiner... & An a unno run the program, the \\
& program \\
Verse 1: & Verse 1: \\
\hline Bum flick pan mi dick young gal & Have yuh ever stop to think wha mek a \\
Come skin out yah a wayay wayaw Rpt) & gal cheat \\
Uhhhhhh! Yuh hear di young gyal a & have you ever ask her if she likes how \\
bawl & yuh dweet \\
When she get up the nine inch tall... & Yuh need to check yuhself before yuh \\
My name, My name, calling out fi di & start kiss yuh teeth. \\
sweetest pain... & Have yuh ever wonder what mek a girl \\
Gydiup Gydiup like she deh pan a & cum \\
donkey's back... & A woman fus fi satisfy before yuh say \\
$=$ Tears a shed but she still want it.. & yuh done... \\
Every ram mi ram di gal bawl out & Most a unno full of pure self praise \\
Mi buddy long like Mt. Everest.... & Hot fire dey yah but the wood naw \\
The length weh mi have can buss up & blaze \\
any middle... & God haffi work a miracle fi mek the dead \\
& raise \\
& Round dem up and lock dem up di days \\
\hline
\end{tabular}

28 Tanya Stephens, "You Nuh Ready Fi Dis Yet" Mad House Label, Jamaica 1996. 29 Tanya Stephens, Yuh Nuh ready Fi Dis Yet Boy" Madhouse Label, Jamaica. 1996 
In the introduction to Little Lenny's above song, he is heard rounding up random prospective "female Buddy Breakers" 30 who may be interested in taking part in his bedroom riding sessionsriding session because of his reference to a galloping "donkey." Once a partner is located, he proceeds to request that she becomes a gymnast by "Bum [in the air and] flick [so that she lands] pan mi dick" ready to begin copulation. The song becomes unnerving when he acknowledges her discomfort as "sweet tears," which is partly due to the length of his manhood-of which he boast can "buss up any woman's middle" section.

This understanding of lovemaking is standardized in Jamaican dancehall. In this light, Tanya Stephens' song becomes pertinent because she questions Jamaican men's sexual hubris. By enquiring if they really do know "how fi make a girl come," while at the same time asking if a women has ever told him "she likes how him dweet"(or in other words makes love), Tanya Stephens highlights sexually incompetent men who subscribe to Little Lenny's sentiments regarding sex. She also shows how their incompetence has influenced their sexually selfishness and over enthusiasm about the size of their genitals and their sexual performance. Tanya concludes that this kind of confidence is due to "pure self praise," which has not been validated by external reviewers. She then issues a final blow to chauvinism in dancehall by observing that "God have to work a miracle to make the dead-malfunctioning genital-raise" in the event of a prospective sexual encounter. This highlights their sexually uselessness. In the words of Stolzoff, this marked the phenomenon where woman performer whose expression of sexual agency ...threatened the dancehall status quo. ${ }^{31}$

The pertinence of Tanya Stephens' song in relation to the sentiments expressed in Little Lenny's "Bum Flick" should not be overlooked. It speaks to the shift in power dynamic between male and female artist in dancehall. This is because during the process of creating their own space in dancehall based on their rules, women became liberated to the point where they could now reprimand misogynistic sentiments about sex without fear of backlash. Tanya's above song was released in 1996, at a time when women's presence in Dancehall became overwhelming powerful. So much so, that an

30 "Buddy" is Jamaican vernacular for the male genital.

${ }^{31}$ Stolzoff, Norman.C . Wake the town and Tell the People,p. 106 
entire industry was created to foster to the "Dancehall Diva's ${ }^{32}$ " need. The dancehall fashion industry has evolved to a point where women are now the engines of the machinery that runs dancehall.

\section{Dancehall Fashion Industry}

While no women became sound system disc jockeys (DJ), they did however create a fashion industry that catered to women of the dancehall. Based on Stolzoff's account, this was partly due to the layout of the dancehall venue, 33 which placed the DJ and his sound system on the perimeter of dancehall. This afforded dancehall participants the room to display their fashion and dance moves 34 in a competitive nature. This was the space that women in dancehall soon took and created a space for competing and displaying their erotic dancing and 'X-rated fashions,' which attracted and maintained the crowd's attention. 35

This dancehall ambiance was successfully recreated in the 1997 movie 'Dancehall Queen.' It was also successful in capturing the independent, strong spirit of Jamaican women ${ }^{36}$ in the dancehall scene on an intimate level. Just like many Dancehall Divas, Marcia (the main character) was a single mother who worked as an 'Igla' (i.e. street vender). Living in a "poverty stricken risk inner city" 37 community in Kingston, Jamaica, Marcia enters in the Dancehall Queen competition in order to win the prize cash out of necessity. She entered the competition, defeated the reigning dancehall queen, and wins the cash prize, but most importantly, she become famous after she was crowned Dancehall Queen. This movie is important because not only did show that any women could become a Dancehall Queen, but also because it informs the public of the work (designing clothes, hair, nails, and make up) that goes into creating a

\footnotetext{
32 Stolzoff, Norman.C. Wake the town and Tell the People,p. 109

33 idib

34 D'Elia, Suzan 2002, Speech:214 Rhetoric of Dancehall Music ( Women's Fashion in Jamaican Dancehall.

http://debate.uvm.edu/dreadlibrary/delia02.html

3535 Stolzoff, Norman.C . Wake the town and Tell the People,108

36 Susan D' Elia, 2002. Speech:214 Rhetoric of Dancehall Music (Women's Fashion in Jamaican Dancehall)

http://debate.uvm.edu/dreadlibrary/delia02.html
}

37 Boston, Thomas, D. 1997. The Inner City: Urban Poverty and economic development. P.190. 
"Dancehall Diva." 38 At this time, women's sovereignty in dancehall became undeniable. Essentially, since it showcased the economy of Jamaican dancehall.

Creating the dancehall queen persona is a collaborative efforts. Point in case, Jamaica's first and most memorable Dancehall Queen, Carlene Davis, who rose to dancehall royalty from not so humble beginnings through a series of dancehall competitions between other dancehall divas ${ }^{39}$ in the 1990s. A dancehall queen must embody dancehall fashion, dancing and, most importantly, attitude. In Chakca Demus and Pliers 1998 music video for their song "Murder She Wrote,"40 dancehall queen Carlene exhibited all three qualifications. In the video, her entire outfit was gold: wig, over sized jewelry, small bra like blouse with 'Ali Baba' like sleeves, batty rider ${ }^{41}$ and gold knee high boots to complete the look. No doubt that number was a result of dancehall's emerging fashion industry.

One of the most infamous designers to emerge from Jamaican dancehall was the Ouch Crew ${ }^{42}$ who was fundamental in the creation of dancehall's unique style. With laces, straps, leather, sequins and chiffons materials, the Ouch Crew was one of the first groups to provide creatively outrageous and revealing women's dancehall fashion of the 1990 s a commodified brand. As a result, pieces from the Ouch brand are to be on display in Manhattan dancehall fashion Museum.43 As dancehall evolved over the years so did its fashion, as there was a moving away from shockingly

\footnotetext{
38 Stolzoff, Norman.C. Wake the town and Tell the People,p108

39 Idib

40 Chacka Demous, Pliers, 2000. Murder she wrote. (Decce, Spectrum).

40 D'Elia, Suzan 2002, Speech:214 Rhetoric of Dancehall Music ( Women's Fashion in Jamaican Dancehall.

http://debate.uvm.edu/dreadlibrary/delia02.html

41 Lewis, Linden. 2003. (The culture of gender in the Caribbean" (Florida: University Press of Florida). P 232

${ }^{42}$ Campbell, Curtis: August 11, 2012The Jamaica Star (Ouch says Dancehall Has Lost its Culture) . http://jamaica-star.com/thestar/20120811/ent/ent1.html

43 idib
} 
outrageous to fashionably outrageous 'glammed' up fashion that is know known as "swagerrific. 44 "

Modern designers emerged within the last decade to represent the new fashion demands in dancehall. On one hand, modern designers like Melissa Dunkley of MDiz Collection,45 Martin 'White Sky' Miller, and Dexter " 3 D" Pottinger ${ }^{46}$ has played a pivotal role in redefining dancehall's fashion from mere nudity to couture nudity. According to The Jamaica Star writer, Tanya C. Ellis, these designers pieces explore the "creations of cliché designer wear, so those like the D\&G, the Dior's and the Prada's are now featured prominently on the front line at major events" 47 while at the same time maintaining its dancehall's flavour. "[P]encil skirt" she continues, "has become the new best friend of these patrons, as they have come to realize that beautifully tailored fitting skirt allows them...to be utterly 'naked' but entirely covered," 48 which has allowed them to maintain sex appeal modestly.

On the other, the hair, make up and nail technicians has played a complementary role in creating the dancehall look. In Anna Alissa short documentary on 'YouTube' by the name of "Street Side Salon," 49 she shows women getting the dancehall at Mathew's Lane, Down Town Kingston, Jamaica. The clip shows hair of several of different colours being assembled in styles and glued on women's head. In another section, the nail technicians are recorded putting on nail lavishly decorated nail tips on customer's fingers while other staff members of the Street Side Salon are viewed attaching on lashes and eyebrows on different customers. The nature of these styles screams dancehall and is designed for women who subscribe to the social practices of dancehall. Admittedly, there are solons located in he upper echelons of Jamaica. However, the adornment services that these salons provide tend to be a bit too tamed for dancehall, and are more suitable for the club scenes, not dancehall.

\footnotetext{
44 Urban dictionary (A person's style; the way they walk, talk, dress). http://www.urbandictionary.com/define.php?term=swagger

${ }^{45}$ http://styleweekjamaica.blogspot.ca/2009/05/mellisa-dunkleyscollection.html

46 Ellis, Tanya. The Jamaica Star: The Changing Image of dancehall (January 19, 2008) http://jamaica-star.com/thestar/20080119/ent/ent4.html $47 \mathrm{Ibid}$

49 http://www.youtube.com/watch?v=te4PkUrAVJM
} 
Dancehall dancing has, as well, evolved from its original state. One of dancehall queen Carlene's legacies is Jamaica's internationally acclaimed Dancehall Queen Completions. Jamaica has had several Jamaican dancehall queens such as Mad Michel, Keivea, Stacey, and Latisha, ${ }^{50}$ but there was one unlikely Jamaican dancehall queen. Originally from Japan, Junko won the Dancehall Queen competition in 2002 at a time when dances moves like 'Log On', 'Zip it Up', 'Angel Dance', 'On Line', 'Screechy', and 'Drive By'51 was popular in dancehall. Since then, international competitors have entered the competition in an attempt to be crowned Jamaica's Dancehall queen. Dancers with associate degree in performing Arts like "Dance Expressions has won Jamaica Cultural Development Commission (JCDC) nationals for dance, speech and drama every year, $5^{2}$ for several years, but is also active on the dancehall scene. Dance Expressions can be seen in Mr. Vegas' song, "Bruk It Dung" 53 doing extensive pelvic thrusting with unbelievable precisions and speed, and head top dancing." 54 Moreover, after a night of displaying fashion and dance moves, one of the beneficial aspects of dancehall is late night jerk chicken with two slices of bread and a cup of soup to replenished dancehall patrons. This is another industry that is derived from female presence in dancehall, as women tend to be the one cooking and selling these delights.

\section{An Observer's Oversight}

In Carolyn Cooper's "Lady Saw Cuts Loose," she response to American anthropologist' Obiagele Lake accusations that Lady Saw "internalizing sexist norms," 55 and in so doing, has perpetuated the victimization of women in dancehall. While Suzan D'Elia hold's that "the average Jamaican woman is not interested in the level of sophistication that American or European women are concerned with." 56 This paper tends to be more supportive to Cooper's

\footnotetext{
50 Henry, Krishna. 2002http://jamaica-

star.com/thestar/20060623/ent/ent1.html

51 Ibid

52 Asher, Kesi, 2005 http://jamaica

gleaner.com/gleaner/20051014/ent/ent6.html

53 Mr. Vegas. 2012 (Mr. Vegas Music/ VPAL) CD Reggae.

54 Stol Stolzoff, Norman.C . Wake the town and Tell the People,p110

${ }^{55}$ Cooper, Carolyne. Lady Caw Cuts Loos. 355

56 D'Elia, Suzan 2002, Speech:214 Rhetoric of Dancehall Music ( Women's Fashion in Jamaican Dancehall.

http://debate.uvm.edu/dreadlibrary/delia02.html
} 
explanation. According to Cooper, Lake's understanding of Lady Saw is a result of her "unseasoned American ear" ${ }^{57}$ which lacks the cultural priming of Jamaican female sexuality from an historical perspective. Cooper's responded by making an historical argument claiming Lady Saw is a "woman who knows the power of her own sexual appeal...and...speaks the truth about her society." 58 Cooper's argument finds its base in making the connection to African Jamaican's historical relationship with the understanding of sex and unconstrained sexuality to have been extended beyond the bounds of colonialism.

One reason why subscribers of Western understanding of sexuality tends to be unable to interpret women in Jamaican dancehall as appositive form of sexual expression may be found in analyzing their historical understanding of female sexuality. According to Carol A.B. Warren, "medical control of female sexuality is part of our western cultural heritage, involving both the woman's physical body and her social place." 59 This "space" includes the "marriage bed, the house hold, and private spaces" ${ }^{60}$ during the Victorian age. In more specific terms, a woman was suspected of suffering from the sickness known as "hysteria," if she was "gnashing of teeth, rolling of eyes, loss of voice, and choking." 61 It is useful to note that some of these characteristics are now known to be expressions of fatigue or frustration. As a cure for hysteria, the doctors believed that applying "genital stimulatory treatment [to] causes orgasm, and thus released the retained matter ${ }^{62}$ from the woman. This form of treatment was, however, mired in the controversies of "Judeo-Christian" narratives, which believed this approach was altogether too sexual, not very clerical ${ }^{63}$ and was eventually stopped. Clearly, Warren's work shows that the West has a strong history in the sexual repression of women. This provides one reason why it is problematic to superimpose on Jamaican

\footnotetext{
57 Cooper 57 Cooper, Carolyne. Lady Caw Cuts Loos. 365

58 Cooper, Carolyne. Lady Caw Cuts Loos. 367

59 Warren. A.B. Carol. 2004. Genetal surgeries and stimulation in Nineteenth Century Psychiatry (Emeral Publishing group Limited) 165.

60 lbid

61 Warren, Carol A.B Warren, 2004 "GENITAL SURGERIES AND STIMULATION IN

NINETEENTH CENTURY (by Elsevier Ltd.All rights) p. 69

62 Warren. A.B. Carol. 2004. Genetal surgeries and stimulation in Nineteenth Century Psychiatry (Emeral Publishing group Limited) 165.

63 ibid
} 
dancehall diva's a Western perspective of what constitutes for correct and decent sexual expressions.

Another reason why observers fail to recognized female sovereignty in dancehall is that it has tendencies to encourage "covert and overt violence against women." 64 On Sunday, September 10, 2010, The Jamaican Observer reported that Bounty Killer "used a hammer to beat" 65 his companion in the head. He was charged for assault, but the case was eventually "thrown out" 66 due to a lack of evidence. Another example of violence against women is Tracey Bennett's and Captain Barkley's murder. They were killed by Tracey's estranged ex-husband on Saturday, October13, 2012 in New York. ${ }^{67}$ Though this happened in New York, Captain Barkley was a Jamaica dancehall artist and both were dancehall patrons. Though these two examples did not take place in the dancehall arena. They are, however, connected with dancehall and are examples of what can transpire in dancehall, perhaps not in practice, but more so in principle.

In conclusion, this paper aims to analytically respond to the inability to recognized female sovereignty in dancehall through sexual expressions. The fact that the dancehall arena was the first place Jamaican working class woman ${ }^{68}$ actively created a space for themselves $\mathrm{s}$ in a post-independent atmosphere made this a place of liberation from societal constraint. Even though foundation female artist provide social commentary of Jamaica's inequalities, they have and continued to be viewed as "consistently slack and indecent." 69

64 Paul, Annie. Brathwaite, Kamau. 2007.Caribbean Culture: Soundings on) 378

Braithwaite

65 http://www.jamaicaobserver.com/news/Bounty-Killer-arrested-

again_7977043

66 Harison, Crystal.The Jamaica Star (Bounty Killer's 'Hammer' Case Thrown Out)

http://jamaica-gleaner.com/latest/article.php?id=26128

67THE JAMAICA STAR, SUNDAY OCTOBER 14, 2012 (Captain Barky shot dead J'can deejay and female companion cut down in Bronx motel parking IN BR http://www.jamaicaobserver.com/news/Captain-Barkey-shot-dead 12749400

68 Stolzoff, Norman.C . Wake the town and Tell the People,p109

69 Cooper, Carolyne. Lady Saw Cuts Loos.362. 
Unfortunately, Lady Saw's reputation of being 'slack' has masked the strength and insight she displayed by tackling issues of infertility in her song "No Less Than A Woman,"70 which is a topic that has been an elephant in Jamaica's room for too many years. As stated by D'Elia, "although the dancehall scene is a male dominated one, it is the female, like a queen, who reigns supreme." ${ }^{71}$

If women's presence is void in a dancehall session, no one will remain in the party. In addition, dancehall provides female participants with opportunity for economic mobility by becoming a dancehall artist, dancehall diva, dancehall queen, dancehall dancers' and even dancehall cooks. One reason why the idea of women achieving liberation and empowerment in dancehall is difficult to accept from outside observers is because of the different understanding of sex and sexual expressions. ${ }^{72}$ These observers tends to look at women in dancehall as victims of sexual objects while not being able to see how women's response to these understandings has changed the discourse in dancehall. A third reason is the possible abuse that women can experience in the dancehall, but if one is truthful, one will admit the prospect of this possibility in any industry. Perhaps if there were a departure from the practice of measuring dancehall women and their willingness to sexually express themselves in reference to European women, then the point of contention would become less rigid.

70 Lady Saw, "No Less Than a Woman"

2007 http://www.youtube.com/watch?v=9ggirUh6Jmo

71 D'Elia, Suzan 2002, Speech:214 Rhetoric of Dancehall Music (Women's

Fashion in Jamaican Dancehall).

http://debate.uvm.edu/dreadlibrary/delia02.html 


\section{CITATIONS}

Alissa, Anna. December 3, 2010. Street Side Salon. http://www.youtube.com/watch?v=te4PkUrAVJM

Asher, Kesi, October 14, 2005 Jamaica Gleaner, Dance Expressions speaks body language"

http://jamaica-gleaner.com/gleaner/20051014/ent/ent6.html

Boston, Thomas, D. 1997. The Inner City: Urban Poverty and economic development.

Campbell, Curtis: August 11, 2012The Jamaica Star (Ouch says Dancehall Has Lost its Culture).

http://jamaica-star.com/thestar/20120811/ent/ent1.html

Chude-Sokie, Louis, 1994. "Post-Nationalist Geographies: Rasta, Ragga, and Reinventing Africa." The African Arts, (UCLA: James S. Coleman Published) Vol. 27, No. 4, pp. 80-84+96

Cooper, Carolyn. 2004 "Lady Saw Cuts Loose: female fertility Rituals in Dancehall" in Sound Clash: Jamaican Dancehall Culture at Large." (New York: Palgrave Publishers)

Ellis, Tanya. The Jamaica Star: The Changing Image of dancehall (January 19, 2008)

http://jamaica-star.com/thestar/20080119/ent/ent4.html

Harison, Crystal.The Jamaica Star (Bounty Killer's 'Hammer' Case Thrown Out) http://iamaica-gleaner.com/latest/article.php?id=26128

Henry, Krishna. 2002 The Jamaica Star: "Junko makes Japan dance" http://jamaica-star.com/thestar/20060623/ent/ent1.html

Lewis, Linden. 2003. "The culture of gender in the Caribbean" (Florida: University Press of Florida). P 232

Stolzoff, Norma. C. 2000 "Wake the town and Tell the People: Dancehall Culture in Jamaica." (North Carolina: Duke University press, 2000) p.104 
Paul, Annie. Brathwaite, Kamau. 2007.Caribbean Culture: Soundings on) 378.

The Jamaican Star: September 19, 2010. "Bounty Killer Arrested Again: Deejay Accused of eating Girlfriend".

http://www.jamaicaobserver.com/news/Bounty-Killer-arrestedagain 7977043

THE JAMAICA STAR, SUNDAY OCTOBER 14, 2012 (Captain Barkey shot dead J'can deejay and female companion cut down in Bronx motel parking IN BR http://www.jamaicaobserver.com/news/Captain-Barkeyshot-dead 12749400

1Lady Saw, “No Less Than a Woman" 2007 http://www.youtube.com/watch?v=9ggirUh6Jmo

Urban dictionary (A person's style; the way they walk, talk, dress). http://www.urbandictionary.com/define.php?term=swagger

Sytle week Jamaica. May 14, 2009.

http://styleweekjamaica.blogspot.ca/2009/05/mellisa-dunkleyscollection.html

Warren, A.B. CAROL "GENITAL SURGERIES AND STIMULATION IN NINETEENTH CENTURY PSYCHIATRY", (ed.) Marcia Segal, Vasilikie Demos, and Jennie Jacobs Kronenfeld, in Gendered Perspectives on Reproduction and Sexuality (Advances inGender Research, Volume 8), Emerald Group Publishing Limited. 